\title{
MAKNA ADJEKTIVA TANOSHII (楽しい) DAN URESHII (嬉しい) SEBAGAI SINONIM (KAJIAN SEMANTIS BAHASA JEPANG)
}

\author{
Mhd. Pujiono, Talia \\ Fakultas IImu Budaya Universitas Sumatra Utara, \\ Fakultas Bahasa dan Komunikasi Universitas Harapan Medan \\ Pos-el: mpoejiono@yahoo.co.id, taulia2013@yahoo.com
}

\begin{abstract}
A bstrak
Tulisan ini bertujuan untuk mendeskripsikan makna tanoshii dan ureshii yang mempunyai makna sama atau sinonim (ruigigo) dalam bahasa Jepang yang merupakan objek kajian semantik (imiron). Di dalam bahasa Jepang banyak sinonim dan sangat sulit untuk dipadankan ke dalam bahasa Indonesia satu-persatu. Walaupun kata-kata yang bersinonim tersebut mempunyai makna yang sama atau hampir sama tetapi dalam pengungkapannya terdapat perbedaan. Perbedaan tersebut dikarenakan makna suatu kata biasanya akan berkembang karena dipengaruhi oleh konteks atau situasi dalam kalimatnya. Karena perbedaan tersebut, muncul kesalahan kebahasaan dalam bahasa Jepang yang dikarenakan informasi makna yang masih kurang lengkap khususnya sinonim, sehingga sering juga menimbulkan kesalahpahaman dalam komunikasi. Penelitian ini menggunakan metodekualitatif yang bersifat deskriptif. Langkah-langkah penelitian adalah mengumpulkan data menggunakan metodesimak dengan teknik catat, menganalisis data, dan menyajikan data secara informal. Dari analisis didapatkan hasil bahwa tanoshii lebih merujuk pada 'proses' ketika suatu aktifitas sedang berlangsung, sedangkan ureshii lebih merujuk pada 'akhir' suatu proses yang biasanya disertai dengan rasa haru.
\end{abstract}

Kata kunci: semantik, sinonim, adjektiva, tanoshii, ureshii

\begin{abstract}
Theresearch describes themeaning of tanoshii and ureshii which havethesamemeaning or synonym (ruigigo) in Japanese which is the object of semantic study (imiron). Thereare many synonyms in Japanese which are very difficult to be paired into Indonesian languageoneby one. Even though thesynonymous words havethe same or al most the same meaning but in the disclosure there are a differences. The differences because the meaning of a word will usually develop because it is influenced by the context or situation in the sentence. Because of thesedifferences, thereis a mistakein thelanguage of Japanesew hich is dueto infor mation meaning that is still not complete, especially synonym, so often al so causemisunderstandings in communication. This research uses descriptive qual itative method. Thesteps of research are coll ecting data using themethod refer to thetechniquerecord, analyzing data, and presenting the data informally. From the analysis it is found that tanoshii refers moreto 'process' when an activity is in progress, whereas ureshii refers moreto the 'end' of a process that is usually accompanied by a senseof emotion.
\end{abstract}

Keywords: semantic, synonym, adjective, tanoshii, ureshii

\section{PENDAHULUAN}

Sampai sekarang masih sering ditemui kesalahan dalam pengungkapan kata-kata berbahasa Jepang, khususnya dikalangan pembe lajar bahasa Jepang. Kesalahan berbahasa pada pembelajar, umumnya terjadi karena adanya transfer negatif bahasa ibu dengan bahasa Jepang. Kesalahan yang muncul bisa berupa penggunaan kosa kata, penggunaan pola kalimat, dan sebagainya (Sutedi, 2003:1). $\mathrm{Hal}$ tersebut bisa dipahami karena selain kurangnya informasi makna yang diperoleh 
pembelajar tersebut, juga kebanyakan dalam pemahaman bahasa asing, khususnya makna kata bahasa Jepang, hanya sebatas melalui terjemahan kata-kata yang dilihat dari kamus tanpa melihat konteks kalimat dimana kata tersebut muncul serta tidak memahami bidang apa yang sedang diterjemahkannya. Dalam hal ini Hasakawa (dalam Chaer 1995:16-17) menyatakan bahwa untuk menemukan arti se buah kata bukanlah membuka kamus sebab arti atau definisi di dalam kamus sifatnya sirkumlokasi. Yang benar adalah kita harus mengamati bagaimana kata itu dipergunakan dalam berbagai teks. Hal yang sama dikemukakan oleh A.J Soegeng (dalam Nandi 2016:110) bahwa betapapun pentingnya kamus dalam proses penerjemahan, hal ini bukan merupakan jaminan mutlak bahwa tugas terjemahan itu akan terselesaikan dengan baik. Di samping penguasaan perbendaharaan kata, tata bahasa, ungkapan, ideomatik, istilah-istilah khusus, dan asal-usul kata, seseorang masih dituntut pula menguasai bidang ilmu yang sedang diterjemahakannya.

Bidang ilmu atau pengetahuan yang merupakan media untuk mempermudah dan memperlancar pemahaman dan penguasaan bahasa adalah pengetahuan linguistik. Salah satu cabang dari linguistik (gengogaku) adalah semantik (imiron) dan objek kajian semantik antara lain adalah sinonim.

Objek kajian pada artikel ini adalah se mantik (imiron) yang merupakan salah satu cabang linguistik (gengogaku) yang mengkaji makna. Adapun maknayang dimaksud adalah khususnya makna kata (go no imi) yang mempunyai makna sama atau hampir sama (sinonim).

Sinonim atau sinonimi adalah hubungan semantik yang menyatakan adanya kesamaan makna antara satu satuan ujaran dengan satuan ujaran lainnya (Chaer, 2007:297).

Dari sekian banyak kata yang bersinonim dalam bahasa Jepang, di antaranya adalah adjektiva tanoshii dan ureshii yang dalam bahasa
Indonesia bisa dipadankan dengan kata 'senang', 'gembira'.

A djektiva dalam bahasa Jepamg terdiri dari dua jenis, yaitu adjektiva (-i) (i-kiyoushii) dan adjektiva (-na) (-na keiyoushii). Menurut Situmorang (2007), i-keiyoushi yang selalu berakhiran -i dan - na keiyou shi yang selalu berakhiran - na atau -da. A dapun ciri-ciri adjektiva bahasa Jepang adalah: dapat berdiri sendiri, menunjukan sifat atau keadaan sesuatu benda, mempunyai perubahan bentuk, dapat menjadi predikat (-i-keiyoushi).

Tanoshii dan ureshii karena berakhiran -i, maka termasuk ke dalam jenis adjektiva -i ( $i$ keiyoushi). Menurut Masayoshi (1994) tanoshii adalah ungkapan suasana yang baik dan ceria tanpa adanya hal-hal yang buruk dan membosankan, sedangkan ureshii mengungkapkan keterharuan dan kegembiraan ketika hal yang diinginkan dan diharapkan sesuai dengan kenyataan. Hal senada diungkapkan Tian \& Izuhara (1998) bahwa tanoshii adalah keadaan yang memuaskan, bernilai positif (plus) tanpa kekurangan apapun, sedangkan ureshii adalah perasaan senang ketika terpenuhinya suatu harapan dan keinginan.

Pada bagian Iain, Ngurah Indra (2012:69-70) mengungkapkan bahwa adjektiva tanoshii memiliki makna yang hampir sama dengan kata senang dalam bahasa Indonesia dan adjektiva ureshii memiliki makna yang hampir sama dengan kata gembira. Tanoshii/gembira merupakan kepuasan bersama, ada rentang waktu dirasakannya, dan dipengaruhi suasana tempat, sedangkan ureshii adalah mengandung makna kepuasan yang lebih individual, bersifat seketika, dan tidak dipengaruhi oleh suasana tempat.

Dipilihnya adjektiva tanoshii dan ureshii karena masih banyak pembelajar bahasa Jepang yang keliru dalam penggunaan kedua adjektiva tersebut sehingga kedengarannya aneh dan membingungkan bahkan pada akhirnya sering menimbulkan kesalahpahaman. Untuk itu, pembelajar bahasa Jepang hendak- 
nya berhati-hati karena bisa saja yang semula bermaksud mengungkapkan penghargaan atau ucapan terima kasih, jika salah memilih kata tanoshii dan ureshii (senang, gembira) tersebut, malah yang diterima sebaliknya.

Contoh ketika pembelajar bahasa Jepang disuruh memilih kata tanoshii dan ureshii untuk mengisi percakapan berikut:

\section{A：はい、誕生日のプレゼント \\ $\mathrm{Hai}$, tanjoubi no purezento \\ ya, ini hadiah ulang tahun}

\section{B: わあ、(楽しい嬉しい)。ありがとう}

Waa,( tanoshii/ureshii). A rigatou

Waa, (saya) senang/ gembira. Terima kasih

Ternyata pembelajar tersebut memiliki jawaban yang bervariasi, ada yang menjawab tanoshii dan ada juga yang menjawab ureshii. Tetapi begitu ditanyakan masing-masing alasan kenapa memilih tanoshii dan kenapa memilih ureshii, maka hampir semuanya menjawab sama saja, karena artinya sama, yaitu senang, gembira. Padahal jawaban yang paling tepat untuk percakapan di atas adalah ureshii. Sebaliknya, jika menjawab tanoshii akan kedengaran aneh dan dapat menimbulkan kesalahpahaman, walaupun kalau dilihat dari makna sama saja.

\section{TEORI DAN METODE}

Artikel ini membahas tentang makna adjektiva bahasa Jepang tanoshii dan ureshii. Ferdinand de Saussure dalam Chaer (2007:287) menyatakan bahwa makna adalah 'pengertian' atau 'konsep' yang dimiliki atau terdapat pada sebuah tanda linguistik. Kalau tanda linguistik disamakan identitasnya dengan kata atau leksem, maka makna adalah pengertian atau konsep yang dimiliki oleh setiap kata atau leksem; kalau tandalinguistik disamakan identitasnya dengan morfem, maka berarti makna itu adalah pengertian atau konsep yang dimiliki oleh setiap morfem.

Makna yang dibahas dalam artikel ini adalah makna kata yang terdapat dalam kon- teks kalimat atau makna kontekstual. Makna kontekstual adalah makna sebuah leksem atau kata yang berada di dalam satu konteks. Makna konteks dapat juga berkenaan dengan situasinya, yakni tempat, waktu, dan lingkungan penggunaan bahasa itu (Chaer, 2007:290)

Adapun makna yang dibahas adalah dua buah kata yang mempunyai makna sama atau hampir sama (sinonim). Sinonim atau sinonimi adalah hubungan semantik yang menyatakan adanya kesamaan makna antara satu satuan ujaran dengan satuan ujaran lainnya (Chaer, 2007:297). Selanjutnya Chaer menyatakan bahwa dua buah kata yang bersinonim tidak akan selalu dapat dipertukarkan atau disubsitusikan.

Sinonim merupakan beberapa kata yang maknanya hampir sama. Hal ini banyak sekali dalam bahasa Jepang, sehingga menjadi salah satu penyebab sulitnya mempelajari bahasa Jepang. Sinonim dalam bahasa Jepang bisa ditemukan tidak hanya pada verba saja, tetapi juga pada nomina, adjektiva, bahkan ungkapan dan partikel pun bisa terjadi (Sutedi, 2003: 121). Sinonim (ruigigo) merupakan salah satu objek kajian semantik (imiron). Imai (1987:128) mengatakan bahwa semantik (asTÖš 'imiron') adalah wilayah yang mengungkapkan bermacam-macam bidang yang berkaitan dengan makna atau arti kata. Umumnya bidang semantik mengungkapkan ketepatan makna kata dan kalimat.

Hal yang sama juga diungkapkan oleh Chaer (1995:2) bahwa semantik sebagai istilah yang digunakan untuk bidang linguistik yang mempelajari hubungan antara tanda-tanda linguistik dengan hal-hal yang ditandainya, atau dengan kata lain bidang studi dalam linguistik yang mempelajari makna atau arti bahasa. Oleh karena itu, semantik dapat diartikan sebagai ilmu tentang makna atau tentang arti.

Penelitian ini adalah penelitian kualitatif yang bersifat deskriptif. Moleong (dalam Gapur, 2017:2016) menjelaskan bahwa pendekatan 
kualitatif menekankan pada proses, maka pe nelusuran data dan informasi secara diakronik akan dilakukan untuk mengetahui dan memahami secara runtut dan lengkap. M engingat esensi metode kualitatif dalam memandang masyarakat itu sebagai subjek, berdasarkan pandangan masyarakat itu sendiri, data yang didapat benar-benar seperti adanya. Tujuan metode kualitatif deskriptif dalam penelitian ini adalah menemukan makna dari data yang dianalisis sehingga dapat dijelaskan fakta secara mendalam dan jelas.

Data penelitian diperoleh dari berbagai kalimat berbahasa Jepang dengan menggunakan metode baca catat, yaitu dengan membaca penggunaan bahasa secara tulisan, kemudian dilanjutkan dengan teknik catat untuk menjaring data untuk dianalisis.

Penyajian hasil analisis data dapat dilakukan dengan dua metode, yaitu metode informal dan metode formal. M enurut Sudaryanto (2015:145) metode penyajian informal adalah perumusan dengan kata-kata biasa. M etode formal adalah perumusan dengan tanda dan lambang-lambang. M etode yang digunakan dalam penyajian hasil analisis data pada penelitian ini adalah metode informal.

\section{HASIL DAN PEMBAHASAN}

Sebelum membahas adjektiva tanoshii dan ureshii, di sini dibahas terlebih dahulu ciri, jenis, dan fungsi adjektiva bahasa Jepang.

\section{A. Ciri dan Jenis Adjektiva Bahasa Jepang}

Dalam bahasa Jepang adjektiva disebut dengan istilah Keiyoushi. Terdapat dua jenis adjektiva atau keiyoushi yaitu i-keiyoushi dan na-keiyoushi. Ciri-ciri kedua adjektiva ini sama, yaitu dapat berdiri sendiri, menunjukan sifat atau keadaan sesuatu benda, serta mempunyai perubahan bentuk (konjugasi).

I-keiyoushi (adjektiva-i) dalam bentuk prenomina berakhiran dengan suara $い(i)$, seperti, samui 'dingin', yasashii ‘mudah', 'ramah'. Secara morfologi adjektiva bahasa Jepang berfungsi sebagai predikat, contoh: sono kaban wa omoi 'tas itu berat', sono kutsu wa takai 'sepatu itu mahal'. Sedangkan na-keiyoushi (adjektiva -na) yaitu berakhiran dengan suara な (na), seperti, bimbou-na, 'miskin', shinsetsu-na 'ramah'. Secara morfologis ketika berfungsi sebagai prenomina berbeda dengan adjektiva-i, yaitu dengan cara menamabahkan -na, seperti bimbouna hito 'orang (yang) miskin', shinsetsuna hito 'orang (yang) ramah'. disebakakan karena tan oshii dan ureshii berakhiran -i, maka tanoshii dan ureshii termasuk ke dalam adjektiva- $\mathrm{i}$ atau i-keiyoushi.

\section{B. Fungsi Adjektiva (keiyoushi)}

Adjektiva -i maupun adjektiva -na, sesuai dengan fungsinya dalam kalimat ada yang mengalami perubahan bentuk dasarnya dan ada yang tidak mengalami perubahan.

1) Sebagai predikat

Adjektiva -i dapat digunakan sebagai predikat dengan tidak mengalami perubahan pada kata sifat dasarnya.

Contoh: Kyou wa atsui desu 'hari ini panas' Kono kutsu wa takai 'sepatu ini mahal'

Demikian juga untuk adjektiva -na berfungsi sebagai predikat dengan tidak ada perubahan pada bentuk dasarnya.

Contoh: M edan wa nigiyaka da 'Medan ramai' $\mathrm{N}$ ihon no koutsuu wa benri da 'transportasi di Jepang praktis'

2) Menerangkan Kata Benda

Adjektiva (-i) tidak mengalami perubahan bentuk dasar ketika menerangkan benda.

Pola: $\quad$ adjektiva $-\mathrm{i}+\mathrm{Kt}$. benda

Contoh: takai yama (B. Jepang)

tinggi gunung gunung (yang) tinggi (B. Indonesia) yasashii hito (B. Jepang) ramah orang

Orang (yang) ramah (B. Indonesia)

Sedangkan adjektiva-na harus menambahkan -na di antara adjektiva dan bendanya. 
Contoh: genki na kodomo 'anak (yang) sehat' N igiyaka na machi 'kota (yang) ramai'

3) Menerangkan Kata Kerja

Adjektiva-i ketika menghadapi kata kerja, maka huruf -i dari bentuk dasarnya dihilangkan dan diganti dengan -ku.

Pola: adjektiva - $\mathrm{i}+\mathrm{ku}+\mathrm{Kt}$. Kerja

Contoh: warui 'jelek' + miemasu 'terlihat'-_ waruku miemasu 'terlihat/ kelihatannya jelek'

Tanoshii 'gembira' + asobimasu 'bermain' - - tanoshiku asobimasu 'bermain (dengan) gembira'

Sedangkan untuk adjektiva-na, hanya dengan menambahkan partikel -ni.

Contoh: kantan ni hanasu 'berbicara dengan singkat'

Nigiyaka ni naru 'menjadi ramai'

\section{Tanoshii (楽しい)}

Tanoshii termasuk ke dalam jenis adjektiva -i (i-keiyoushii) dan mempunyai makna senang, gembira. Tanoshii digunakan untuk mengungkapkan rasa senang yang erat kaitannya dengan keadaan atau situasi ketika suatu aktivitas sedang berlangsung.

Contoh :

1 私は家族と話しているときが一番楽しい。 Watashi wa kazoku to hanashite iru toki ga ichiban tanoshii.

Saya paling senang ketika sedang ngobrol bersama keluarga.

2. 私は時々楽しかった子供の頃を思い出す。 Watashi wa tok-idoki tanoshikatta kodomo no koro o omoidasu.

Saya kadang-kadang teringat masa anakanak yang menyenangkan.

Dalam kalimat (1) tanoshii menyatakan perasaan senang/ gembira yang dirasakan subjek ketika berlangsungnya suatu aktivitas. Faktor yang membuat subjek senang/ gembira adalah (話しているとき hanashite iru toki) 'ketika sedang ngobrol', yaitu suasana ketika sedang ngobrol/ berceritera dengan keluarga. $\mathrm{Hal}$ ini juga ditegaskan dengan pemakaian pola ... te iru pada kata hanashite iru. Hanashite iru berasal dari kata hanasu 'berbicara, ngobrol' yang diubah ke dalam bentuk ... te iru menjadi hanashite iru 'sedang ngobrol/ berbicara'.

Kalau melihat kalimat (1) di atas, kata tanoshii juga bisa juga digunakan dalam aktivitas yang menyenangkan dalam kurun waktu tertentu. Dalam kalimat tersebut kurun waktunya adalah selama sedang ngobrol dengan keluarga dan terlepas dari apa yang diceritakannya atau apa yang terjadi setelah aktivitas tersebut. Seperti dapat dilihat dalam kalimat (2), bahwa tanoshii menyatakan rasa senang dalam kurun waktu tertentu, yaitu (子供の頃 kodomo no koro) 'masa anak-anak' dengan segala aktivitasnya. Berbeda dengan kalimat (1) yaitu bahwa bentuk kalimat yang digunakan adalah ...... te iru yang menyatakan bahwa kegiatan sedang berlangsung. Sedangkan dalam kalimat (2) bentuk kalimat yang digunakan adalah bentuk lampau yang ditandai dengan bentuk ... ta pada kata tanoshikatta. Hal ini menunjukan bahwa situasi tersebut sudah lewat (masa anakanak).

Situasi yang sama juga ditunjukan pada kalimat berikut:

夏休みのキャンプは、料理を作ったり

3. 魚を釣ったりしてとても楽しかった。

$\mathrm{N}$ atsu yasumi no kyanpu wa, ryouri o tsukuttari sakana o tsuttari shite totemo tanoshikatta.

Kemping pada libur musim panas sangat menyenangkan karena (kami) bisa memasak dan mancing ikan.

Dalam kalimat (3) tan oshii berubah menjadi tanoshikatta karena waktunya sudah lampau. Kurun waktu ditunjukan dengan 'kemping pada libur musim panas' dengan kegiatan atau aktivitasnya adalah memasak dan memancing. 
4. 楽しい休㮩を過ごす。

Tanoshii kyuukei o sugosu (B. Jepang)

senang istirahat/ libur partikel melewati

Melewati liburan yang menyenangkan (B. Indonesia)

Dalam kalimat (4) tidak t erdapat perubahan bentuk apapun (...te iru maupun ...ta) baik dalam adjektiva tanoshii maupun dalam verba sugosu. Hal ini menunjukan bahwa aktivitas liburan masih dilakukan dan masih terus berlangsung. Pendeknya, kalimat tersebut mengandung pengertian 'melewati masa liburan dan terus masih (akan) melewatinya dengan senang/ gembira'. Situasi yang sama ditunjukkan dengan kalimat berikut.

\section{5. 楽しい日々}

Tanoshii hibi (B. Jepang)

senang hari-hari/ dari hari ke hari

Hari-hari yang menyenangkan (B. Indonesia)

\section{6. 楽しい生活}

Tanoshii seikatsu (B. Jepang)

senang hidup

Hidup yang enak (menyenangkan) (B. Indonesia)

Mengenai penggunaan ungkapan tanoshii ini, untuk lebih jelasnya kita simak percakapan berikut.

7. Ali : 田中さん、写真、ありがとう。旅行 は楽しかったですか。

Tanaka san, shashin, arigatou. Ryokou wa tanoshikatta desu ka?

Tanaka san, terima kasih kiriman fotonya. Bagaimana perjalanan/ wisatanya menyenangkan?

Tanaka: ええ、トバ湖はとてもきれいでしたよ。

Ee, toba ko wa totemo kirei deshita yo.

Ya....., Danao Toba betul-betul cantik.
Dalam percakapan di atas bisa dipastikan bahwa kejadiannya sudah berlalu. Hal ini ditunjukan dengan penggunaan bentuk ......ta baik dalam kata tanoshikatta maupun dalam kata deshita. Penggunaan ungkapan tanoshii (tan oshikatta) yang diucapkan oleh Ali merujuk pada situasi ketika aktivitas yang lalu sedang berlangsung, yaitu pada saat Tanaka melakukan perjalanan atau wisata ke Danau Toba.. Sedangkan kata deshita yang diucapkan oleh Tanaka juga menunjukan bahwa aktivitas sudah lewat/ berlalu dan menurut dia ketika melakukan perjalan tersebut menyenangkan/ menggembirakan dengan jawaban mengiyakan pertanyaan Ali secara implisit dengan hanya menjawab Ee... toba ko wa kirei deshita yo (ya...Danau Toba sangat cantik).

\section{Ureshii (嬉しい)}

Sama halnya dengan tanoshii, ureshii juga termasuk kedalam jenis adjektiva-i (i-keiyoushii) yang maknanya senang, gembira.

Contoh:

\section{8. 卒業して嬉しい \\ sotsugyoushite ureshii \\ (saya) senang karena lulus 0}

Pada kalimat (8) adjektiva yang digunakan adalah ureshii. Faktor yang menimbulkan kesenangan atau kegembiraan adalah 卒業して sotsugyoushite 'lulus'. Dalam kalimat tersebut tidak ada perubahan bentuk apapun dalam adjektiva ureshii. Hal ini bukan berarti bahwa kejadiannya belum terjadi, tetapi peristiwanya sudah terjadi dan perasaan atau emosi dari rasa senangnya sampai sekarang bahkan mungkin di waktu yang akan datang masih akan berbekas. Subjek atau pembicara dalam hal ini merasa sudah banyak mempersiapkan segala sesuatunya baik waktu, usaha, dan tenaga dengan harapan supaya dia berhasil dan lulus, sehingga begitu lulus dia mengungkapkannya dengan rasa suka cita dan perasaan seperti itu kemungkinan akan terus dikenang- 
nya. Hal yang sama juga diungkapkan dalam contoh kalimat berikut.

9.その時、孫が生まれたという嬉しい知らせが届いた。 Sono toki, mago ga umareta to iu ureshii shirase ga todoita.

Waktu itu, (telah) datang kabar yang menyenangkan bahwa cucu telah lahir.

10. 私は病気の時、友達が励ましくてくれてとても嬉しかった。 Watashi wa byouki no toki, tomodachi ga hagemashite kurete totemo ureshii

Ketika sakit, karena teman-teman memberikan dorongan/ semangat saya sangat senang

Faktor yang membuat senang atau gembira pada kalimat (9) adalah 孫が生まれた mago ga umareta 'cucu telah lahir'. Kata ureshii yang dipergunakan pada kalimat tersebut di atas mengungkapkan ekspresi perasaan senang/ gembira dan mungkin juga disertai dengan perasaan terharu dari seorang kakek atau nenek ketika mendengar berita cucunya telah lahir. Dia senang dan terharu karena kelahiran cucunya tersebut bagi kebanyakan orang merupakan sesuatu yang telah lama ditunggu-tunggu dan diinginkannya. A kan lain pulajika kalimat tersebut menggunakan tanoshii, yaitu bahwa si kakek atau nenek hanya merasa senang de ngan datangnya berita yang diterimanya tanpa adanya perasaan apapun apalagi sampai menunggu dan mengharap kelahiran cucunya.

Sama halnya pada kalimat (10) faktor yang membuat subjek senang/gembira adalah 友だちが励ましてくれて tomodachi ga hagemashite kurete 'teman-teman memberikan semangat/ dorongan/ membesarkan hati'. Kata ureshii menunjukan ungkapan perasaan se nang disertai rasa haru bahwa dia telah sembuh berkat semangat dan dorongan yang diberikan kawan-kawannya. Dorongan dan semangat yang diberikan kawan-kawannya biasanya dalam keadaan sakit dibutuhkan sebagai spirit untuk menambah kepercayaan dirinya demi kesembuhannya. Tetapi akan terasa lain jika menggunakan ungkapan tanoshii. Kedatangan teman-temannya merupakan hal yang mungkin tidak diharapkan apalagi mengharapkan dorongan dan semangat. Kedatangan temantemannya yang membuat subjek senang hanyalah penampilan dan tingkah lakunya saja dan jika ungkapan tanoshii ini diucapkan subjek di depan teman-temannya tentunya akan mengakibatkan salah pengertian.

Baik dalam kalimat (9) maupun (10) kejadiannya sudah lampau. Hal ini ditandai dengan その時.......届いた sono toki ...... todoita 'waktu itu .... (telah) datang' dan 病気の時........嬉しかった byouki no toki ....... totemo ureshikatta 'ketika sakit ....... sangat senang/ gembira'. Dalam kedua kalimat tersebut selain terlihat jelas dengan keterangan waktu yang digunakan, juga dipertegas dengan pemakaian bentuk ... .ta baik dalam verba todoita maupun adjektiva ureshikatta.

Setelah membahas ungkapan tanoshii dan ureshii seperti dalam contoh kalimat di atas, untuk lebih jelasnya kita lihat contoh dalam kasus lain yang menggunakan tanoshii dan ureshii berikut.

Seorang mahasiswa setelah melewati massa kuliah selama 4 atau 4,5 tahun yang diIaluinya dengan suka dan duka, akhirnya bulan lalu lulus dan diwisuda yang tentunya dia merasa senang.

Pada kasus di atas ada dua faktor yang membuat subjek senang/ gembira, yaitu 'ketika dia kuliah' dan 'ketika lulus' dan diwisuda. Kedua ungkapan rasa senang tersebut jika diungkapkan dalam kalimat, akan ada ungkapan rasa senang yang berbeda, yaitu tanoshii dan ureshii, yaitu:

11. 学生の時はとても楽しかった。 Gakusei no toki wa totemo tanoshikatta. Ketika mahasiswa sangat menyenangkan

12. 先月卒業して嬉しかった。 Sengetsu sotsugyoushite ureshikatta (saya) sangat senang karena bulan Ialu (telah) lulus 
Dari kedua contoh kalimat di atas dapat dilihat bahwa kalimat (11) menggunakan kata tanoshii karena menunjukan aktivitas dalam kurun waktu tertentu, yaitu ketika dia jadi seorang mahasiswa dengan segala aktivitasnya dan dia merasa senang/ gembira. Sedangkan pada kalimat (12) menggunakan ureshii yang menunjukan bahwa situasi tertentu sudah dilaluinya dengan suka dan duka dan apa yang selama ini diinginkannya akhirnya berhasil, yaitu ditandai dengan lulus dan diwisuda dan bahkan mungkin disertai rasa terharu. Bentuk kalimat dari kedua contoh di atas sama-sama mengguna kan bentuk ... ta (lampau), yaitu tanoshikatta dan ureshikatta karena kedua kalimat tersebut sama sama menyatakan waktu yang telah lewat.

Kata tanoshii dan ureshii pada kedua kalimat di atas masing-masing tidak bisa didistribusikan, karena akan menjadi tidak gramatikal.

\section{E. Tanoshii dan Ureshii bisa disubsitusi}

Dalam situasi atau keadaan tertentu tanoshii dan ureshii bisa disubsitusikan, seperti pada frase berikut.

楽しい/嬉しい手紙 (Ngurah Indra, 2012)

tanoshii/ureshii tegami (B. Jepang)

senang/ gembira surat

surat yang menyenangkan (B. Indonesia)

Kedua adjektiva (tanoshii dan ureshii) pada frase di atas bisa saling menggantikan karena sama-sama menerangkan nomina, yaitu surat. Makna yang terkandung bersifat abstrak, karena jenis suratnya tidak jelas. Jika subjek mengungkapkan rasa senangnya dikarenakan bentuk dan tampilan dari surat tersebut tanpa membaca isi suratnya, maka adjektiva tanoshii lebih tepat. Tetapi jika subjek mengungkapkan rasa senangnya setelah selesai membaca seluruh isi surat, maka adjektiva ureshii yang lebih tepat. Contoh lain:

\section{楽しい/嬉しい音楽}

tanoshii/ ureshii ongaku (B. Jepang)

senang musik

musik yang menyenangkan (B. Indonesia)
Jika subjek dalam mengungkapkan rasa senangnya dengan hanya menggunakan panca indra, yaitu pendengaran, kemungkinan dengan menggerak-gerakan tubuh mengikuti alunan musik, hanya mengikuti irama dan nadanya selama musik mengalun, maka adjektiva tan oshii lebih tepat. Tetapi jika subjek mengungkapkan rasa senangnya dengan penghayatan dan penuh perasaan terhadap musik tersebut, maka adjektiva yang tepat adalah ureshii.

Situasi yang sama dapat dilihat pada kalimat berikut.

ここの仕事は楽しい/嬉しい。

Koko no shigoto wa tanoshi/ureshii (B. Jepang)

Di sini partikel pekerjaan partikel senang

(saya) senang bekerja di sini (B. Indonesia)

Jika subjek dalam mengungkapkan rasa senangnya disebabkan situasi di tempat kerja yang membuatnya senang, misalnya rekan-rekan kerja yang toleransi, pimpinan yang bijaksana sehingga membuatnya kerasan bekerja, maka adjektiva tanoshii lebih tepat. Tetapi jika (dia) bekerja di tempat tersebut merupakan realita dari keinginan dan harapannya selama ini, maka adjektiva ureshii lebih tepat.

君が来てくれて楽しい/嬉しい。 Kimi ga kitekurete tanoshii/ureshii (B. Jepang) Anda partikel datang senang/gembira (saya) senang/ gembira anda datang (B. Indonesia)

Pada kalimat di atas, jika subjek dalam mengungkapkan rasa senangnya disebabkan dengan kedatangan orang tersebut dapat menimbulkan rasa senang/ gembira, misalnya karena kebiasaannya, seperti penampilan, gaya bicara yang lucu, menghibur yang dapat membuat senang, maka adjektiva tanoshii lebih tepat. Tetapi jika kedatangan orang tersebut telah ditunggu-tunggu dan diharapkan kedatangannya atau juga bahkan mungkin datang sengaja untuknya, sehingga dengan kedatangannya telah membuat perasaannya tenang, 
menimbulkan rasa haru (mungkin sampai me nangis), maka adjektiva ureshii lebih tepat.

Setelah menyimak pembahasan antara adjektiva tanoshii dan ureshii, makajika kembali ke percakapan di awal:

A：はい、誕生日のプレゼント

$\mathrm{H}$ ai, tanjoubi no purezento (B. Jepang)

Ya, ulang tahun partikel hadiah

$\mathrm{Ya}$, ini hadiah ulang tahun (B.Indonesia)

B: わあ、(楽しい嬉しい)。ありがとう Waa,( tanoshii/ureshii). A rigatou (B. Jepang) Waa, (senang/ gembira). Terima kasih

Waa, saya senang/ gembira. Terima kasih (B. Indonesia)

Pengungkapan rasa senang, gembira pada percakapan di atas yang tepat dan lebih baik diucapkan si B adalah ureshii. Dengan mengucapkan ureshii, terlepas si B mengharap atau tidaknya terhadap pemberian hadiah dari si $A$, ucapan si B betul-betul menimbulkan kesenangan/ kegembiraan yang penuh dengan emosi keterharuaan. Dia merasa diperhatikan sehingga menghargai pemberian apapun yang diterimanya walaupun tanpa melihat apa isi pemberian tersebut. Ulang tahun merupakan waktu yang spesial bagi seseorang, sehingga siapapun yang datang atau hanya sekedar memberikan perhatian pada waktu itu, terlebih orang yang datang tersebut merupakan orang yang dianggap istimewa bagi dirinya apalagi disertai dengan memberikan sesuatu (hadiah), tentunya akan menimbulkan perasaan senang/ gembira dan terharu. Sedangkan jika si B mengungkapkan rasa senangnya dengan mengucapkan tanoshii, selain tidak gramatikal, si A akan bingung atau mungkin merasa bahwa perhatian dan pemberiannya tidak dihargai. Penggunaan tanoshii pada percakapan tersebut kurang tepat, artinya bahwa si B merasa senang, gembira bukan karena perhatian dan pemberian hadiah yang diterimanya, tetapi lebih kepada penampilan pisik, gerak tubuh, yaitu cara si A ketika memberikan hadiah, atau juga karena kado/ hadiah yang diberikan tersebut menarik dari segi tampilan dan bentuknya saja.

\section{PENUTUP}

A djektiva tanoshii dan ureshii termasuk ke dalam jenis adjektiva -i (i-keiyoushi) dan mempunyai makna yang hampir sama dengan kata senang, gembira dalam bahasa Indonesia, lebih tepatnya bahwa tanoshii lebih kepada makna yang hampir sama dengan kata 'gembira' dan ureshii lebih kepada makna yang hampir sama dengan kata 'senang'.

Persamaan antara adjektiva tanoshii dan ureshii adalah subjeknya sama-sama manusia, berfungsi menyampaikan suasana hati, mempunyai kesan positif, dan menunjukan emosi kepuasan.

Perbedaan antara adjektiva tanoshii dan ureshii adalah, tanoshii ungkapan rasa gembira yang lebih merujuk kepada 'proses' dan ada rentang waktu ketika suatu aktifitas sedang berlangsung. Sedangkan ureshii adalah rasa senang lebih merujuk kepada kepuasan yang lebih individual, misalnya ketika telah tercapainya suatu keinginan atau harapan dan biasanya disertai dengan perasaan terharu.

Dalam kenyataannya bahwa penggunaan tan oshii dan ureshii ada yang bisa disubsitusikan dan ada juga yang tidak bisa disubsitusikan tergantung pada suasana hati dan perasaan serta kepuasan subjek.

\section{DAFTAR PUSTAKA}

Chaer, A bdul. 1995. Pengantar Semantik Bahasa Indinesia. Jakarta : Rineka Cipta

Chaer, Abdul. 2007. Linguisti U mum. Jakarta : PT. Rineka Cipta

Gapur, Abdul. 2017. Upaya Pengurangan Interferensi Gramatikal Bahasa Indonesia dalam Pembelajaran Bahasa Jepang. Genta Bahtera Jurnal IImiah Kebahasaan dan Kesastraan Vol. 3 No. 2.

Imai, Kunihiko.1987. Gendai Gengogaku 20 Shou. Tokyo: Taishukan Shoten 
M asayoshi, Hirose. 1994. Effective Japanese U sage Guide. Tokyo: Kodansha

Nandi S. 2016. U ngkapan M akna Verba Shikaru Dan O koru Sebagai Sinonim. Jurnal Bahasa Universitas Negeri Medan (online) http:// digilib.unimed.ac.id/id/eprint/1323 (dilihat pada 18 Mei 2018)

N gurah Indra, Pradhana. 2012. A nalisis Komparatif U reshii, Tanoshii, dan Y orokobashii D alam Bahasa Indonesia. Sumedang: Unpad
Situmorang, Hamzon. 2007. Pengantar Linguistik Bahasa Jepang. Medan: USU Press

Sudaryanto. 2015. M etode dan A neka Tehnik A nalisis Bahasa (Pengantar Penelitian Wahana Kebudayaan secara Linguistik). Yogyakarta: Duta Wacana University Press.

Sutedi, Dedi. 2003. D asar-dasar Linguistik Bahasa Jepang. Bandung: Humaniora Utama Press Tian, Zhongkui \& Izuhara, Shoji. 1998. Ruigigo. Tokyo: Kenkyusha 